\title{
Analisis Strategi Pemasaran Dan Kualitas Pelayanan Terhadap Kepuasan Konsumen Pada RM. Pepes Ayam
}

\author{
Soewito $^{1}$, Fidelia Isnainy ${ }^{2}$ \\ ${ }^{1}$ Fakultas Ilmu Sosial Dan Ilmu Politik, Universitas Bandar Lampung \\ Jl. Zainal Abidin Pagar Alam No.26, Labuhan Ratu, Kedaton, 35142, Bandar Lampung, Indonesia \\ E-mail: \\ soewito@ubl.ac.id \\ fidelia.17121022@student.ubl.ac.id
}

\begin{abstract}
ABSTRAK
Persaingan yang terus menjadi ketat dengan kemajuan serta pergantian style hidup masyarakat yang terus menjadi modern, perilaku pelanggan pada keputusan pembelian sesuatu produk pula turut bermacam-macam. Tujuan dari riset ini merupakan buat mengenali strategi pemasaran serta mutu pelayanan terhadap kepuasan pelanggan pada Rumah Makan Pepes Ayam PakNana Bandar Lampung. Jenis riset yang digunakan merupakan pendekatan deskriptif memakai regresi linier berganda. Hasil riset membuktikan kalau strategi pemasaran serta mutu pelayanan mempengaruhi dengan kepuasan pelanggan pada Rumah Makan Pak Nana Bandar Lampung. Strategi pemasaran serta mutu pelayanan mempengaruhi signifikan terhadap kepuasan pelanggan. Rumah Makan Pepes Ayam Pak Nana Bandar Lampung hendaknya tingkatkan strategi pemasaran semacam kesesuaian harga, promosi yang dilakukan serta melakukan diskon pada hari besar, lalu meningkatkan mutu pelayanan supaya kepuasan konsumen bisa terpenuhi.
\end{abstract}

Kata Kunci: strategi pemasaran; kualitas pelayanan; kepuasan konsumen 


\section{Pendahuluan}

Pertumbuhan industri kuliner terus menjadi bertambah dikala ini sebab kuliner ialah kebutuhan sehari-hari dari masyarakat. Tetapi seiring dengan pertumbuhan era kuliner tidak hanya menjadi produk mengkonsumsi saja melainkan dikala ini kuliner telah jadi style hidup dari masyarakat. Perihal tersebut terlihat dari kegiatan makan serta minum bersama teman atau kerabat yang dimanfaatkan pula sebagai ajang sosialisasi ataupun kumpul bersama. Hingga tidak heran bila perkembangan industri kuliner di Indonesia diperkirakan hendak terus menjadi meningkat serta semakin bertambah ini pastinya jadi kesempatan menarik untuk para pengusaha bisnis kuliner. Industri kuliner di kota Bandar Lampung yang dikala ini lagi tumbuh sudah mengenali ketatnya persaingan. Untuk itu Rumah Makan Pepes Ayam Pak Nana, tetap membagikan kepercayaan serta harapan kepada segala pelanggan nya buat terus membagikan kepuasan kepada mereka lewat inovasi serta cita rasa yang tidak berganti dari produk yang bermutu serta memiliki nilai lebih dan berupaya mempertahankan pelayanan yang mencukupi maupun tingkatkan pelayanan nya, sehingga nampak berbeda dengan perusahaan lain. Meski begitu, keluhan dari pihak pelanggan ada saja senantiasa terdapat misalnya pelannggan merasakan kurang puas atas pelayanan nya yang dikasih pada makna terjalin ketidakselarasan atas ketidakselarasan antara harapan dengan tuntutan nya.

Dari sekian banyak perhal yang jadi bahan pertimbangan konsumen buat penuhi seluruh kriteria yang jadi bahan pertimbangan konsumen, dalam bisnis keberlanjutan dimaksud selaku keahlian buat mempunyai serta mempertahankan daya saing yang berkepanjangan (Takwi 2020). Pemasaran produk serta pelayanan sangat memegang kedudukan yang sangat berarti apakah konsumen sudah puas ataupun belum dengan produk yang ditawarkan dengan pelayanan yang ada dirumah makan. Bila perihal tersebut diabaikan hingga hendak terjalin kesenjangan antara kemauan (harapan) konsumen dengan pelayanan rumah makan. Semacam dalam perihal kebersihan serta fasilitas (tangibles), kehandalan (reliability), Kecepatan serta pemberian informasi yang komplit serta pas (responsiveness), berikan perhatian yang tulus (empathy), serta membagikan kenyamanan serta keamanan (asurance) dengan dipenuhinya perhal ini hingga kesenjangan anatara rumah makan dengan konsumen nya tidak butuh terjalin.

Tujuan dari riset ini sendiri ialah buat mengenali strategi pemasaran serta mutu pelayanan trhadap kepuasan konsumen pada Rumah Makan Pepes Ayam Pak Nana Bandar Lampung.

\section{Tinjauan Pustaka}

Bagi Assauri (dalam Junaedi 2020), mengartikan strategi pemasaran selaku sesuatu rencna yang komprehensif, terintegrasi, serta terpadu pada bidang pemasaran yang membeagikan pedoman atas aktivitas-aktivitas yang hendak dicoba guna menggapai tujuan pemasaran suatu perusahaan. Menurut Kotler serta Keller (dalam Muis 2021), kalau inti dari pemasaran merupakan mengenali serta penuhi kebutuhan manusia serta sosial. Pemasaran yang pas bisa memastikan kenaikan penjualan serta posisi perusahaan di pasar.

Bagi Wijaya (dalam Runtunuwu et.al 2014), mutu layanan merupakan dimensi seberapa keren layanan yang dikasih sanggup sesuai dengan ekspektasi konsumen. Christopher (dalam Ercis et al 2020), menyatakan dalam menjalankan ikatan jangka panjang dengan pelanggan serta kepuasan pelanggan, menyediakan layanan pelanggan serta mutu bersama. Layanan pula mengacu pada pasar transaksi oleh pengusaha dimana obyeknya transaksi tidaklah suatu yang berwujud, juga buka pengalihan kepemilikan (Kotler dalam Andreti et.al 2013). Menurut Ilieska (dalam Amha 2020), kepuasan pelanggan bisa membagikan data kepada perusahaan buat merampingkan pembedahan 
mereka serta memfokuskan program revisi pada pencapaian efisiensi biaya buat pada kesimpulannya menggapai kinerja yang lebih baik.

Menurut Solimun dan Fernandes (dalam Sopasoap 2020), mengatakan kalau kepuasan pelanggan bisa dimaksud selaku kesenangan yang dialami oleh pelanggan kala mengevaluasi sesuatu produk ataupun jasa tertentu yang sudah mereka pakai. Penting untuk konsumen buat mengenali tentang produk yang ditawarkan kepada mereka sebab pemahaman mencerminkan kepuasan orang yang terkait dengan produk tersebut dari permasalahan yang bisa jadi timbul akibat minimnya data ( Taylor dalam Ibrahim et.al 2020).

\section{Metode Penelitian}

Jenis riset ini ialah penelitian yang bersifat kuantitatif deskriptif. Analisis riset deskriptif ialah metode ilmiah yang digunakan buat mendapatkan informasi yang digunakan buat tujuan tertentu (Sugiyono dalam Putri 2021), mendeskripsikan umumnya tentang karakteristik atau guna pasar (Malhotra dalam Zena et.al 2012), serta riset lapangan ialah riset yang dicoba dengan observasi langsung ke objek riset buat memperoleh data.

Populasi ialah tempat generalsasi yang terdri atas obyek ataupun subyek yang miliki mutu serta ciri trtentu yang resmikan oleh periset buat pelajari setelah itu ditarik kesimpulan nya (Sugiyono dalam Runtunuwu 2014). Sampel ialah sebagian dari jumlah ciri yang dipunyai oleh populasi(Sugiyono dalam Runtunuwu 2014). Sampel ialah sebagai yang wakili populasi. Sampel pada riset ini sebesar 100 narasumber. Metode pengumpulan informasi dengan cara observasi, wawancara, dokumentasi, serta kuesioner.

Riset ini mempunyai 2variabel riset ialah, variabel independent (bebas) serta variabel defendent (terikat):

1. Variabel independent (bebas)

Variabel independent pada riset ini merupakan variabel strategi pemasaran (X1) serta kualitas pelayanan (X2).

2. Variabel defendent (terikat)

Variabel defendent dalam riset ini merupakan variabel kepuasan konsumen (Y).

Riset ini makai skala likert ialah dipakai buat ukur perilaku, pendapat seorang orang tentang fenomena sosial (Sugiyono dalam Soewito 2020). Buat keperluan analisis kuantitaif riset ini hingga kepada responden diberi alternatif jawaban dengan memakai skala 1-5 yang bisa dilihat selaku berikut:
A. Sangat setuju = bobot 5
B. Setuju = bobot 4
C. Kurang setuju = bobot 3
D. Tidak setuju = bobot 2
E. Sangat tidak setuju = bobot 1

\section{Hasil dan Pembahasan}

Dalam riset ini narasumber yang mengisi kuesioner merupakan pelanggan Rumah makan Pepes Ayam Pak Nana Di Bandar Lampung. Berlandaskan jenis kelamin, maka narasumber pada riset ini diklarifikasikan sebagai berikut:

Tabel 1. Responden Jenis Kelamin

\begin{tabular}{|c|c|c|c|}
\hline No & Jenis Kelamin & Frekuensi & Persentase \\
\hline 1. & Pria & 54 & $54 \%$ \\
\hline 2. & Wanita & 46 & $46 \%$ \\
\hline
\end{tabular}




\section{a. Uji Validitas}

\begin{tabular}{|c|c|c|}
\hline Jumlah & 100 & $100 \%$ \\
\hline
\end{tabular}

Sumber data: Data diolah oleh peneliti 2021

Dalam riset ini pengujian validitas serta reliabilitas terhadap instrument riset dicoba terhadap 100 orang responden, tiap-tiap kuesioner disiapkan jawaban sebanyak 5 interval jawaban. Jawaban terbawah diberi nilai 1 serta jawaban paling tinggi diberi nilai 5. Uji validitas membuktikan sepanjang mana sesuatu alat ukur sanggup ukur apa yang mau diukur. Bila $r_{\text {hitung }}>$ dari $r_{\text {tabel }}$ (pada taraf signifikasi 5\%), hingga pernyataan tersebut nyatakan valid. Bila $r_{\text {hitung }}$ negatif serta $r_{\text {hitung }}<r_{\text {tabel }}$, hingga perihal ini berarti unit persoalan tersebut nyatakan tidak valid. Pengujan validitas sepenuhnya lihat pada tabel 2 . Berikut ini:

Tabel 2. Hasil Uji Validitas

\begin{tabular}{|c|c|c|c|c|}
\hline No. & Variabel/Indikator & $\mathbf{r}_{\text {hitung }}$ & $\mathbf{r t}_{\text {abel }}$ & Kesimpulan \\
\hline & Strategi Pemasaran & & & \\
\hline 1. & $\mathrm{X} 1.1$ & 0,88 & 0,1966 & Valid \\
\hline 2. & $\mathrm{X} 1.2$ & 0,865 & 0,1966 & Valid \\
\hline 3. & $\mathrm{X} 1.3$ & 0,866 & 0,1966 & Valid \\
\hline 4. & $\mathrm{X} 1.4$ & 0,885 & 0,1966 & Valid \\
\hline \multirow[t]{2}{*}{5.} & $\mathrm{X} 1.5$ & 0,735 & 0,1966 & Valid \\
\hline & \multicolumn{2}{|l|}{ Mutu Pelayanan } & 0,1966 & Valid \\
\hline 1. & $\mathrm{X} 2.1$ & 0,91 & 0,1966 & Valid \\
\hline 2. & $\mathrm{X} 2.2$ & 0,895 & 0,1966 & Valid \\
\hline 3. & $\mathrm{X} 2.3$ & 0,892 & 0,1966 & Valid \\
\hline 4. & $\mathrm{X} 2.4$ & 0,91 & 0,1966 & Valid \\
\hline \multirow[t]{2}{*}{5.} & $\mathrm{X} 2.5$ & 0,907 & 0,1966 & Valid \\
\hline & \multicolumn{2}{|l|}{ Kepuasan Konsumen } & 0,1966 & Valid \\
\hline 1. & Y1.1 & 0,888 & 0,1966 & Valid \\
\hline 2. & Y1.2 & 0,892 & 0,1966 & Valid \\
\hline 3. & Y1.3 & 0,857 & 0,1966 & Valid \\
\hline 4. & Y1.4 & 0,885 & 0,1966 & Valid \\
\hline 5. & Y1.5 & 0,909 & 0,1966 & Valid \\
\hline
\end{tabular}

Sumber Data: Data diolah oleh peneliti 2021

Bersumber tabel 2. Hasil pengujian validitas diatas bisa lihat kalau seluruhan unit variabel riset memiliki $r_{\text {hitung }}>r_{\text {tabel }}$ ialah taraf signifikan 5\% diperoleh $r$ tabel $=0,1966$, hingga bisa didapati $r$ hasil setiap unit> 0,1966 , sehingga dibilang kalau seluruhan item variabel riset merupakan valid buat dipakai selaku instrument pada riset ataupun pernyataan yang diajukan bisa dipakai buat ukur variabel yang ditelti.

\section{b. Uji Reliabilitas}

Sehabis dicoba uji validitas, berikutnya dicoba uji reliabilitas. Uji reliabilitas ialah rangkian pengukuran ataupun rangkain alat ukur yang mempunyai konsistnsi bilapada pengukuran yang dicoba dengan alat ukur itu dicoba secara kesekian. Pada pengujian kuesioner digunakan rumus alpha chronbach dengan menyamakan nilai alpha chronbach dengan nilai $r$ tabel. Sesuatu variabel bisa dikatakan reliabel bila membagikan nilai koefisien reliabilitas chronbach alpha (a) $>0,06$.

Tabel 3. Hasil Uji Reliabilitas Variabel

\begin{tabular}{|l|c|c|c|}
\hline Indikator Variabel & Cronbach's & Cronbach's & Keterangan \\
\hline
\end{tabular}




\begin{tabular}{|l|c|c|c|}
\hline & Alpha & Alpha Standardized & \\
\hline Strategi Pemasaran & 0,898 & 0,6 & Reliabel \\
\hline Mutu Layanan & 0,943 & 0,6 & Reliabel \\
\hline KepuasanKonsumen & 0,932 & 0,6 & Reliabel \\
\hline
\end{tabular}

Sumber Data: Data diolah oleh peneliti 2021

Bersumber pada hasil uji reliabilitas membuktikan kalau variabel strategi pemasaran (X1), variabel mutu pelayanan (X2), sertavariabel kepuasan pelanggan (Y) miliki nilai cronbach's alpha 0,06. Jadi bisa disimpulkan semua pengukuran dari responden kuesioner ialah reliabel (bisa diandalkan), sehingga buat unit tiap-tiap variabel tersebut cocok dipakai sebagai alat ukur serta bisa dicoba pengujian berikutnya.

\section{c. Koefisien Determinasi}

Koefisien determinasi ( $\mathrm{R}$ square ataupun $\mathrm{R}$ kuadrat) ataupun dsimbolkan "R2" yang makna selaku sumbangsih pengaruh yang diperoleh variabel bebas ataupun variabel independet $(\mathrm{X})$ terhadap variabel terikat $(\mathrm{Y})$ ataupun dengankata lain nilaii koefisien determinasi ataupun $\mathrm{R}$ square buat prediksi serta memandang berapa besar kontribusi pengaruhi yang diperoleh variabel X secara bersamasama (simultan) terhadap Y.

Tabel 4. Koefisien Determinasi (R)

\begin{tabular}{|l|c|c|c|c|}
\hline Model & $\mathbf{R}$ & $\begin{array}{c}\mathbf{R} \\
\text { Square }\end{array}$ & $\begin{array}{c}\text { Adjusted } \\
\text { R Square }\end{array}$ & $\begin{array}{c}\text { Std. Error Of } \\
\text { The Estimate }\end{array}$ \\
\hline 1 & $.876^{\mathrm{a}}$ & 0.767 & 0.762 & 1.480 \\
\hline
\end{tabular}

Sumber Data: Data diolah oleh peneliti 2021

Bersumber pada ouput diatas nilai koefisien determinasi ( $\mathrm{R}$ square) merupakan senlai 0767 ataupun sama dengan $76,7 \%$ perihal ini memiliki makna kalau variabel strategi pemasaran (X1) serta variabel mutu pelayanan (X2) secara simultan (bersamasama) mempengaruhi signifkan tehadap variabel kepuasan konsumen (Y).

\section{d. Koefisien Regresi}

Pada penelitian ini analisa regresi linier berganda dipakai buat ngenali ikatan antara variabel independen strategi pemasaran serta mutu pelayanan terhadap variabel dependet (kepuasan konsumen) pada model regresi riset. Dalam analisa regresi linier berganda yang dipakai pada riset ini merupakan dengan menggunaka bantuan program komputer SPSS. Ringkasan hasil pengolahan informasi dengan memakai SPSS selaku berikut:

Tabel 5. Koefisien Regresi Strategi Pemasaran Dan Mutu Pelayanan Terhadap Kepuasan Pelanggan

\begin{tabular}{|c|c|c|c|c|c|c|}
\hline \multirow[t]{2}{*}{ Model } & & Unstandardized & Coefficients & $\begin{array}{l}\text { Standardized } \\
\text { Coefficients }\end{array}$ & $\mathbf{t}$ & Sig. \\
\hline & & B & Std. Error & Beta & & \\
\hline \multirow[t]{3}{*}{1.} & (Constant) & 2.455 & 1.086 & & 2.261 & 0.026 \\
\hline & $\begin{array}{l}\text { Strategi } \\
\text { Pemasaran }\end{array}$ & 0.380 & 0.070 & 0.399 & 5.417 & 0.000 \\
\hline & $\begin{array}{l}\text { Mutu } \\
\text { Pelayanan }\end{array}$ & 0.515 & 0.71 & 0.536 & 7.271 & 0.000 \\
\hline
\end{tabular}

Sumber Data: Data diolah oleh peneliti 2021 
Bersumber pada tabel diatas membuktikan kalau nilai koefisien regresi bisa dibuat persamaan kepuasan konsumen rumah makan pepes ayam pak nana:

Penjelasan:

$$
\begin{aligned}
& \mathrm{Y}=\mathrm{a} 0+\mathrm{b} 1 \mathrm{X} 1+\mathrm{b} 2 \mathrm{X} 2+\mathrm{e} \\
& \mathrm{Y}=2,455+0,380+0,515 \mathrm{X} 2
\end{aligned}
$$

X1 = Strategi Pemasaran Rumah Makan Pepes Ayam Pak Nana

X2 = Kualitas Pelayanan Rumah Makan Pepes Ayam Pak Nana

$\mathrm{Y}=$ Kepuasan Konsumen Rumah Makan Pepes Ayam Pak Nana

Bersumber pada hasil persamaan regresi linier berganda, tiap-tiap variabel menjelaskan kalau:

a. Konstanta (a) $=2,455$

Pada persamaan diatas nilai konstanta didapati sebesar 2,455 (positif), yang berarti kalau nilai skor pada strategi pemasaran (X1) serta mutu pelayanan (X2) sama dengan nol, hingga kepuasan konsumen (Y) sama dengan 2,455.

b. Koefisien regresi strategi pemasaran (b1) $=0,380$

Koefisien strategi pemasaran sebesar 0,380, bermakna berarti kalau tiap peningkatan 1 strategi pemasaran dari rumah makan pepes ayam pak nana bisa tingkatkan kepuasan konsumen sebesar 0,380. Nilai koefisien strategi pemasaran yang bernilai positif pula berarti kalau terus menjadi baik strategi pemasaran hingga kepuasan konsumen terus menjadi besar.

c. Koefisien regresi mutu pelayanan (b2) $=0,515$

Koefisien mutu pelayanan sebesar 0,515 , bermakna tiap peningkatan 1 mutu pelayanan dari rumah makan pepes ayam pak nana bisa tingkatkan kepuasan konsumen sebesar 0,515. Nilai koefisien strategi pemasaran yang bernilai positif pula berarti kalau terus menjadi baik mutu pelayanan hingga kepuasan konsumen hingga menjadi besar.

\section{e. Uji Parsial (Uji T)}

Pengujian parsial dipakai buat mengenali penaruh ataupun ikatan variabel independent serta dependent dimana salah satu variabel dependent nya terbuat senantiasa. Hasil uji t bisa lihat padaoutput coefficient darihasil analisa regrsi liner berganda dengan memakai bantuan program SPSS. Pengujian riset ini dicoba dengan tingkatan kepercayaan $95 \%$ melalui ketentuan sebagai berikut:

1. Bila $t_{\text {hitung }}>t_{\text {tabel }}(0,05)$, hingga Ha didukung serta Ho tidak didukung.

2. Bila $t_{\text {hitung }}>t_{\text {tabel }}(0,05)$, hingga Ha tidak didukung serta Ho didukung Buat mengenali gimana pengaruh hipotesis nya bsa dlihat dri tabel berikut:

Tabel 6. Uji Hipotesis Parsial (Uji T)

\begin{tabular}{|c|c|c|c|c|c|c|}
\hline Model & \multicolumn{2}{|c|}{$\begin{array}{c}\text { Unstandardized } \\
\text { Coefficients }\end{array}$} & $\begin{array}{c}\text { Standardized } \\
\text { Coefficients }\end{array}$ & $\mathbf{t}$ & Sig. \\
\hline & B & $\begin{array}{c}\text { Std. } \\
\text { Error }\end{array}$ & Beta & & \\
\hline 1. & (Constant) & 2.455 & 1.086 & & 2.261 & 0.026 \\
\hline & $\begin{array}{c}\text { Strategi } \\
\text { Pemasaran }\end{array}$ & 0.380 & 0.070 & 0.399 & 5.417 & 0.000 \\
\hline & $\begin{array}{l}\text { Mutu } \\
\text { Pelayanan }\end{array}$ & 0.515 & 0.071 & 0.536 & 7.271 & 0.000 \\
\hline
\end{tabular}

Sumber Data: Data diolah oleh peneliti 2021 
berikut:

Bersumberpada tabel diatas pengujian variabel-variabel bebas bisa dilihat sebagai

1. Variabel strategi pemasaran dengan tingkatan keyakinan signifikasi $5 \%(\mathrm{a}=$ $0,05)$ senilai $0,000<0,05$ serta $t_{\text {hitung }} 5,147>t_{\text {tabel }} 1,66071$, hingga $\mathrm{H} 1$ didukung serta Ho tidak didukung secara parsial variabel strategi pemasaran mempengaruhi positif signifikan terhadap kepuasan pelanggan pada rumah makan pepes ayam paknana di Bandar Lampung.

2. Variabel mutu pelayanan dengan tingkatan keyakinan $5 \%(a=0,05)$ senilai $0,000<0,05$ serta $t_{\text {hitung }} 7,271>t_{\text {tabel }} 1,66071$, hingga $\mathrm{H} 2$ didukung serta Ho tidak didukung sehingga secara parsial variabel mutu pelayanan mempengaruhi positif signifkan terhadap kepuasan pelanggan pada rumah makan pepes ayam paknana di Bandar Lampung.

\section{f. Uji Simultan (Uji F)}

Uji simultan ataupun ujiF buat mengenali ikatan variabel bebas secra bertepatan (simultan) terhadap variabel terkait ialah variabel strategi pemasaran serta mutu pelayanan terhadap kepuasan konsumen dengan ketentuan dinyatakan mempengaruhi signifikan bila sig. $<$ a $(0,05)$. Buat mengenali variabelbebas secara bertepatan bisa dilihat selaku berikut:

Tabel 7. Uji Hipotesis Simultan (Uji F)

\begin{tabular}{|l|l|l|c|l|c|c|}
\hline Model & & $\begin{array}{l}\text { Sum of } \\
\text { Squares }\end{array}$ & df & $\begin{array}{l}\text { Mean } \\
\text { Square }\end{array}$ & F & Sig. \\
\hline 1. & Regression & 700.826 & 2 & 350.413 & 159.905 & $.000^{\mathrm{b}}$ \\
\hline & Residual & 212.564 & 97 & 2.191 & & \\
\hline & Total & 913.390 & 99 & & & \\
\hline
\end{tabular}

a. Dependent Variabel: Kepuasan pelanggan

b. Predictors: ( Constant ), Mutu Pelayanan , Strategi Pemasaran

Sumber Data: Data diolah oleh peneliti 2021

Bersumber pada tabel diatas didpati nilai signifikan buat pengaruh strategi pemasaran serta mutu pelayanan secara simultan terhadp kepuasan pelanggan senilai $0,000<0,05$ daan fhitung 159,905 > ftabel 3,09 sehingga bisa disimpulkan kalau H3 didukung serta Ho tidak didukung yang berarti bahwa strategi pemasaran serta mutu pelayanan secara bersama-sama mempengaruhi positif sgnifikan terhadapkepuasan konsumen pada rumah makan pepes ayam pak nana Bandar Lampung.

\section{Kesimpulan Dan Saran}

\section{a. Kesimpulan}

Bersumberpada hasil riset serta ulasan yang dicoba mengenai Analisis Strategi Pemasaran Dan mutu Pelayanan Terhadap Kepuasan Konsumen Pada Rumah Makan Pepes Ayam Nana Di Kota Bandar Lampung, hingga bisa disimpulkan bahwa:

1. Strategi pemasaran mempengaruhi terhadap kepuasan konsumen pada makan pepes ayam paknana di Bandar Lampung.

2. Mutu pelayanan mempengaruhi trhadap kepuasan konsumen pada rumah makan pepes ayam paknana di Bandar Lampung.

3. Strategi pemasaran serta mutu pelayanan mempengaruhi terhadap kepuasan pelanggan pada rumah makan pepes ayam paknana di Bandar Lampung.

\section{b. Saran}


Bersumber pada hasil riset ini, ada pula saran yang bisa saya berikan buat riset berikutnya yaitu sebagai berikut:

1. Periset berikutnya dianjurkan supaya perbanyak responden kuesioner supaya hasil riset lebih signifikan.

\section{Daftar Pustaka}

Amha, G. G. (2020). Determinants of customer satisfaction and customer loyalty in Amhara Credit and Saving Institute (ACSI): The case of Waghimera Zone Sekota Town. International Journal of Marketing \& Human Resource Research, 1(1), 34-51.

Andreti, J., Zhafira, N. H., Akmal, S. S., \& Kumar, S. (2013). The Analysis of Product , Price , Place, Promotion and Service Quality on Customers' Buying Decision of Convenience Store : A Survey of Young Adult in Bekasi, West Java, Indonesia International Journal of Advances in Management and Economics The Analy. International Journal of Advances in Management and Economics, 2(6), 72-78. www.managementjournal.info\%0ASometimes

Degerlendirmesi, S. M. (2020). Iliskisel Pazarlama Boyutlarının Musteri Baglılıgı Uzerindeki Etkisi : The Influence of Relationship Marketing on Customer Loyalty : Evaluation of Shammout's Model. 595-605.

Hasbiah, S., \& Ruma, Z. (n.d.). Marketing Strategy in Furniture Business in Takalar District. $1551-1558$.

Junaedi, I. W. R. (2021). Soto Kwali Solo Mbok Darmi'S Family Business Strategy in Increasing Sales in Semer 50, Kerobokan, Kuta, Badung Regency, Bali. International Journal of Family Business Practices, 3(2), 47. https://doi.org/10.33021/ijfbp.v3i2.1334

Mbah Takwi, F., \& Atabongfua Mavis, A. (2020). The Effects of Logistic Management on Enterprise Performance: A Case of Gas Depot Atem in Yaounde Cameroon. American Journal of Operations Management and Information Systems, 5(3), 41. https://doi.org/10.11648/j.ajomis.20200503.12

Muis, M., Juhari, J., \& Rachmawati, M. (2021). Analysis of the Effectiveness of Pb Djarum Advertising Scholarship Using the Epic Method in 2020. Dinasti International Journal of Management Science, 2(3), 347-359. https://doi.org/10.31933/dijms.v2i3.693

Mohd Azizi Ibrahim, A. M. N. \& R. R. I. R. H. (2020). CONTRACTOR INTENTION ON CONTRACTORS' ALL RISK TAKAFULPRODUCT IN MALAYSIAN CONSTRUCTION INDUSTRYe. 690.

Putri, K. N., \& Hermawan, D. (2021). Digital Marketing Strategy of Creative Consultant during COVID-19 Pandemic : a Qualitative Approach. 1(1), 39-56.

Runtunuwu, J., Oroh, S., \& Taroreh, R. (2014). Pengaruh Kualitas Produk, Harga, Dan Kualitas Pelayanan Terhadap Kepuasan Pengguna Cafe Dan Resto Cabana Manado. Jurnal Riset Ekonomi, Manajemen, Bisnis Dan Akuntansi, 2(3), 1803-1813. https://doi.org/10.35794/emba.v2i3.5973 
Soewito, Gheany Febidhanty, Suwandi, A. H. (2020). THE ANALIZE OFRELATIONSHIP MARKETING (CUSTOMER MARKETING) AND CUSTOMER SATISFACTION ON CUSTOMER LOYALTY OF PT TELKOMSEL BANDAR LAMPUNG. 15, 16.

Soewito, I. K. T. P. (2017). PENGARUH KUALITAS PELAYANAN TERHADAP KEPUASAN PELANGGAN TAKSI ARGOMETER PADA PT PUSPA JAYA TAKSI DI BANDAR LAMPUNG. 10, 19

Sopasoap, P., Srunjaicheun, K., Padungyat, P., Sangobjit, P., Thongbaiyai, S., Sachot, P., Boonthiam, P., \& Thanuttamanon, B. (2020). SERVICE MARKETING MIX AND SERVICE QUALITY INFLUENCING CUSTOMERS ' SATISFACTION IN USING 7ELEVEN. 4(2), 58-69

Sulistyo, A., Pariwisata, S. T., \& Yogyakarta, A. (2021). Sme 's Strategy i n Creating Sustainable Business During Covid-19 Towards the New Normal Era Based on Marketing Mix Perspective. 34(Ahms 2020), 200-204.

Zena, P. A., \& Hadisumarto, A. D. (2013). The Study of Relationship among Experiential Marketing, Service Quality, Customer Satisfaction, and Customer Loyalty. ASEAN Marketing Journal, 4(1), 37-46. https://doi.org/10.21002/amj.v4i1.2030 